\title{
DISTRIBUTION OF FUNDS UNDER THE DIRECT SUPPORT SCHEME BETWEEN BENEFICIARIES - ANALYSIS OF INEQUALITY AND REDISTRIBUTIVE INSTRUMENTS INTRODUCED IN 2015
}

\begin{abstract}
The paper analyses the inequality of distribution between beneficiaries of the EU aid implemented under the system of direct support and assessment of the level of use by the European Union Member States of the redistributive potential of instruments introduced by way of the 2015 Common Agricultural Policy reform. These are especially important issues in the context of aiming at ensuring fair division of funds allocated to agriculture support, not weakening the incentives to raise efficiency.

The empirical data were sourced from factsheets of total amounts of direct payments paid to beneficiaries broken down by the EU Member States and support quotas. The research used descriptive statistics methods, comparative analysis and simulations.

It was stated that the degree of use of the redistributive potential of instruments reducing the inequalities in the amount of support per a beneficiary granted by a given state does not depend on its place as regards inequality of division of funds between farmers. It may give evidence of different perception of the decision-makers in various countries on the fair division of support. Moreover, some recommendations were formulated as regards redistributive instruments introduced by way of the 2015 CAP reform. According to the author, the mechanism of payments reduction should not be limited only to the basic payment, additionally there should be a possibility to adjust the quota limit at the level of a Member State. This would increase the redistributive potential of this mechanism. At the same time, according to the author, Member States use the possibilities of increasing the significance of redistributive
\end{abstract}


payment to an insufficient degree by increasing the level of the instrument financing. Such solution allows for gradual decrease in the level of support concentration, thus avoiding rapid changes in the income situation of the beneficiaries of direct payments.

Keywords: direct payments, support concentration, Gini coefficient, Lorenz curve, redistributive payment.

JEL codes: H23, Q14, Q18.

\section{Introduction}

The unequal distribution of direct support among farmers is an issue widely discussed by both publicists and the academia. It was an important topic in the discussion on the future of the Common Agricultural Policy (CAP), which took place before the 2015 reform.

According to Zawojska (2006), larger farms should not benefit more from direct payments. She is critical of the distribution pattern under the direct support scheme, emphasizing that it fails to mitigate income disparities among farms. When summarizing their research findings, Sinabell, Schmid and Hofreither (2009) state that the volume of direct payments tends to be concentrated in a small number of large farms and that this situation has remained unchanged for some time. They believe that a greater reduction of payments made to the largest farms could improve the distribution of direct support. Similarly, the signatories of Common Agricultural Policy for European Public Goodsdeclaration adopted in $2009^{1}$ questioned the fairness of the direct support scheme, pointing out to significant disparities in the amounts granted to individual farmers. Wilkin (2009) points out that the distribution of CAP resources is directly linked with the socio-political legitimacy of this policy. The polarization of benefits stirs up strong emotions in the society, and therefore, in his view, a more egalitarian distribution of resources between beneficiaries is necessary. On the other hand, Czyżewski and Stępień (2011) suggest that greater assistance be provided to small farms and that a minimum level of direct payments should be introduced for them, while introducing a limit for direct payments made to the largest farms.

The aim of the present study is to analyse the unequal distribution of the EU funding under the direct support system and to assess the extent to which Member

\footnotetext{
${ }^{1}$ M. Hofreither (Austria), J. Swinnen (Belgium), P. Mishev (Bulgaria), T. Doucha (Czech Republic), S.E. Frandsen (Denmark), R. Värnik (Estonia), K. Pietola (Finland), S. von Cramon-Taubadel (Germany), J. Popp (Hungary), A. Matthews (Ireland), G. Anania (Italy), A. Miglavs (Latvia), I. Kriščiukaitienẻ (Lithuania), G. Faber (Netherlands), J. Wilkin (Poland), F.X. Miranda de Avillez (Portugal), D. Gavrilescu (Romania), L. Bartova (Slovakia), E. Erjavec (Slowenia), J.M. Garcia Alvarez-Coque (Spain), E. Rabinowicz (Sweden), A. Swinbank (Great Britain), V. Zahrnt (Germany).
} 
States use the redistributive potential of instruments introduced through the 2015 CAP reform. Therefore, the analysis refers to the disparities of the amount of support granted to individual farmers in a given EU Member State (EU), without discussing the distribution of direct payments between Member States. ${ }^{2}$

\section{Research methodology}

The analysis of unequal distribution of resources among the beneficiaries of the EU direct support system was carried out on two levels: vertical (comparison of the degree of concentration of direct payments in Poland in subsequent years) and horizontal (comparison of the degree of concentration of direct payments in Poland with other EU Member States). The Gini coefficient (G) was applied to measure the degree of concentration; it is calculated according to the following formula (Wasilewska, 2011):

$$
G=\frac{0,5-\sum_{i=1}^{k} \frac{\left(z_{i}^{\text {skum }}+z_{i-1}^{\text {skum }}\right) \times w_{i}}{2}}{0,5}
$$

where:

$i=1,2, \ldots, k-$ class number of frequency distribution,

$k-\quad-$ number of ranges (classes) in frequency distribution,

$z_{i}^{\text {skum }} \quad-$ cumulative index of the general structure of the sum of values for the range with number $i$,

$z_{i-1}^{\text {skum }}-$ cumulative index of the general structure of the sum of values of the characteristic for the range with number $i-1$,

$w_{i} \quad-$ indicator of the number structure for the range with number $i$.

Its takes values from the range $[0 ; 1]$. The 0 value means an even distribution of funds, while 1 - their total concentration. The Lorenz curve was used to represent the concentration phenomenon graphically.

The variable is the amount of direct payments received by a farmer in a given year. The total sum of the value of a characteristic, that is the variable's total fund, is the total amount of funds paid to all direct support beneficiaries in a given Member State in the course of a given year. The frequency distribution encompasses 14 classes. The subsets identified within it consist of farmers receiving support whose amount is consistent with the range of the given class.

In order to investigate changes in the degree of concentration of direct support in Poland, data from the period between 2009 and 2014 was analysed, with particular emphasis on the first and last year of this period. At present, this is

\footnotetext{
${ }^{2}$ Analyses pertaining to the criteria that apply to the allocation of the EU funds earmarked for direct support of agriculture among the EU Member States can be found, e.g. in studies authored by Hamulczuk and Rembisz (2009), and Krzyżanowski (2015).
} 
the most recent six-year period for which European Commission data allowing the analysis of this phenomenon is available. ${ }^{3}$ In addition, data for each year of that period is characterized by the same level of detail (i.e. the European Commission presents it as 14 ranges, while data for 2001-2004 is broken down into 11 ranges and data for 2005-2008 into 12 ranges). On the other hand, data from 2014 was used in international comparisons of support concentration levels. Empirical research was carried out with respect to the period between 2009 and 2014 , i.e. the period immediately preceding the implementation of the reformed direct support system.

The remaining part of the study refers to changes in the direct support system that came into force in 2015, affecting the equality of distribution of funds between beneficiaries. In addition to the identification of instruments that affect the distribution of support, instrument implementation options from each Member State were reviewed. Thus, the level of redistribution potential of Member States could be assessed. Mathematical methods, comparative analysis and simulations were the main research methods employed in this part of the study.

\section{Analysis of changes in the concentration of support in Poland}

In 2009, beneficiaries of the lowest amounts (less than EUR 5,000), representing $97 \%$ of all Polish beneficiaries, received $64 \%$ of the total amount of support, while the largest farmers (beneficiaries of support exceeding EUR 50,000), representing $0.1 \%$ of all beneficiaries, received in total an amount representing $12 \%$ of funding allocated under the direct support scheme. In 2014, farmers who were granted support up to EUR 5,000 accounted for $91 \%$ of all beneficiaries and received $50 \%$ of the total amount earmarked for the scheme, while support for the farms that were paid EUR 50,000 or more (just over $0.3 \%$ of all farms) represented $14 \%$ of the national payment threshold. Thus, during the analysed period, the 6 percentage points drop in the share of farms receiving less than EUR 5,000 coincided with a 14 percentage points decrease in their share in the total amount of funds earmarked for support. At the same time, the number of beneficiaries receiving EUR 50,000 and more increased, both in terms of their number (by 0.2 percentage point) and the amount of funds received (by 2 percentage points). For the analysed characteristic, the Gini coefficient for 2014 equals $G_{P L 2014} \cong 1-0,39 \cong 0,61$. Results of auxiliary calculations are summarized in Table 1 .

\footnotetext{
${ }^{3}$ List of direct payments made to beneficiaries, organized by Member States and the amount of support (as published by the European Commission) were used as source data. The European Commission prepares them on the basis of data received annually from the EU Member States. They allow us to moniter of trends and prepare of forecasts for the beneficiaries of direct support.
} 
Table 1

Concentration of direct support in Poland in 2014

\begin{tabular}{|c|c|c|c|c|c|c|c|}
\hline 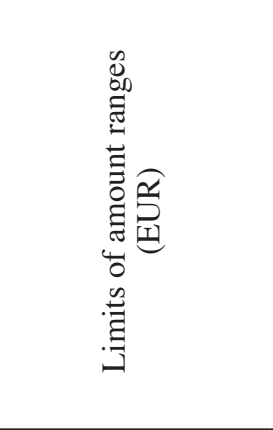 & 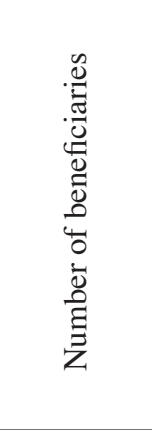 & 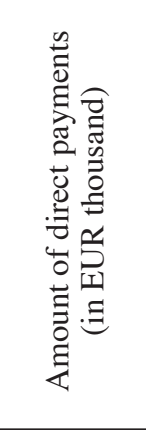 & 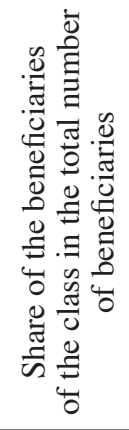 & 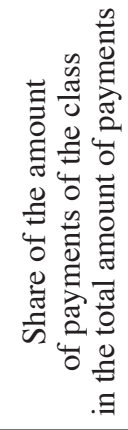 & 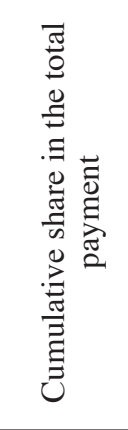 & 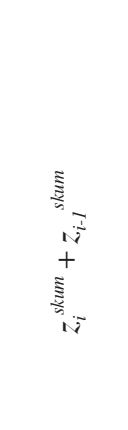 & 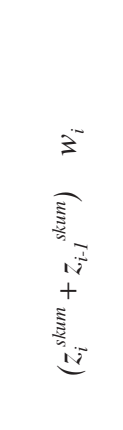 \\
\hline$\left[x_{0 i} ; x_{1 i}\right)$ & $n_{i}$ & $m_{i}$ & $w_{i}=\frac{n_{i}}{n}$ & $z_{i}=\frac{m_{i}}{m}$ & $z_{i}^{\text {skum }}$ & & \\
\hline$[0 ; 500)$ & 303,835 & 104,362 & 0.22539 & 0.03113 & 0.03113 & 0.03113 & 0.00702 \\
\hline$[500 ; 1,250)$ & 426,092 & 351,219 & 0.31608 & 0.10475 & 0.13587 & 0.16700 & 0.05278 \\
\hline$[1,250 ; 2000)$ & 212,134 & 337,033 & 0.15736 & 0.10052 & 0.23639 & 0.37227 & 0.05858 \\
\hline$[2,000 ; 5,000)$ & 284,108 & 874,374 & 0.21075 & 0.26078 & 0.49717 & 0.73356 & 0.15460 \\
\hline$[5,000 ; 10,000)$ & 81,054 & 551,220 & 0.06013 & 0.16440 & 0.66157 & 1.15874 & 0.06967 \\
\hline$[10,000 ; 20,000)$ & 26,730 & 361,167 & 0.01983 & 0.10772 & 0.76929 & 1.43086 & 0.02837 \\
\hline$[20,000 ; 50,000)$ & 10,214 & 297,276 & 0.00758 & 0.08866 & 0.85795 & 1.62723 & 0.01233 \\
\hline$[50,000 ; 100,000)$ & 2,464 & 168,902 & 0.00183 & 0.05037 & 0.90832 & 1.76627 & 0.00323 \\
\hline$[100,000 ; 150,000)$ & 703 & 84,732 & 0.00052 & 0.02527 & 0.93359 & 1.84191 & 0.00096 \\
\hline$[150,000 ; 200,000)$ & 304 & 52,142 & 0.00023 & 0.01555 & 0.94914 & 1.88273 & 0.00042 \\
\hline$[200,000 ; 250,000)$ & 140 & 31,007 & 0.00010 & 0.00925 & 0.95839 & 1.90753 & 0.00020 \\
\hline$[250,000 ; 300,000)$ & 77 & 21,026 & 0.00006 & 0.00627 & 0.96466 & 1.92305 & 0.00011 \\
\hline$[300,000 ; 300,000)$ & 142 & 53,180 & 0.00011 & 0.01586 & 0.98052 & 1.94518 & 0.00020 \\
\hline$[500,000 ; \infty)$ & 65 & 65,308 & 0.00005 & 0.01948 & 1.00000 & 1.98052 & 0.00010 \\
\hline Total & $1,348,062$ & $3,352,948$ & 1.00000 & 1.00000 & $\mathbf{x}$ & $\mathbf{x}$ & 0,38858 \\
\hline
\end{tabular}

Source: own study based on Indicative figures... (financial year 2015).

Gini coefficient had the same value in 2009, 2011 and 2012, while in the remaining years of the surveyed period (2010 and 2013) it amounted to 0.60. This can be interpreted as a strong and stable concentration of direct support in Poland during the studied period. The stability of the degree of concentration of the EU support distributed under the direct support scheme in 2009-2014 is confirmed by nearly overlapping Lorenz curves for the first and last years of this period (Figure 1). 


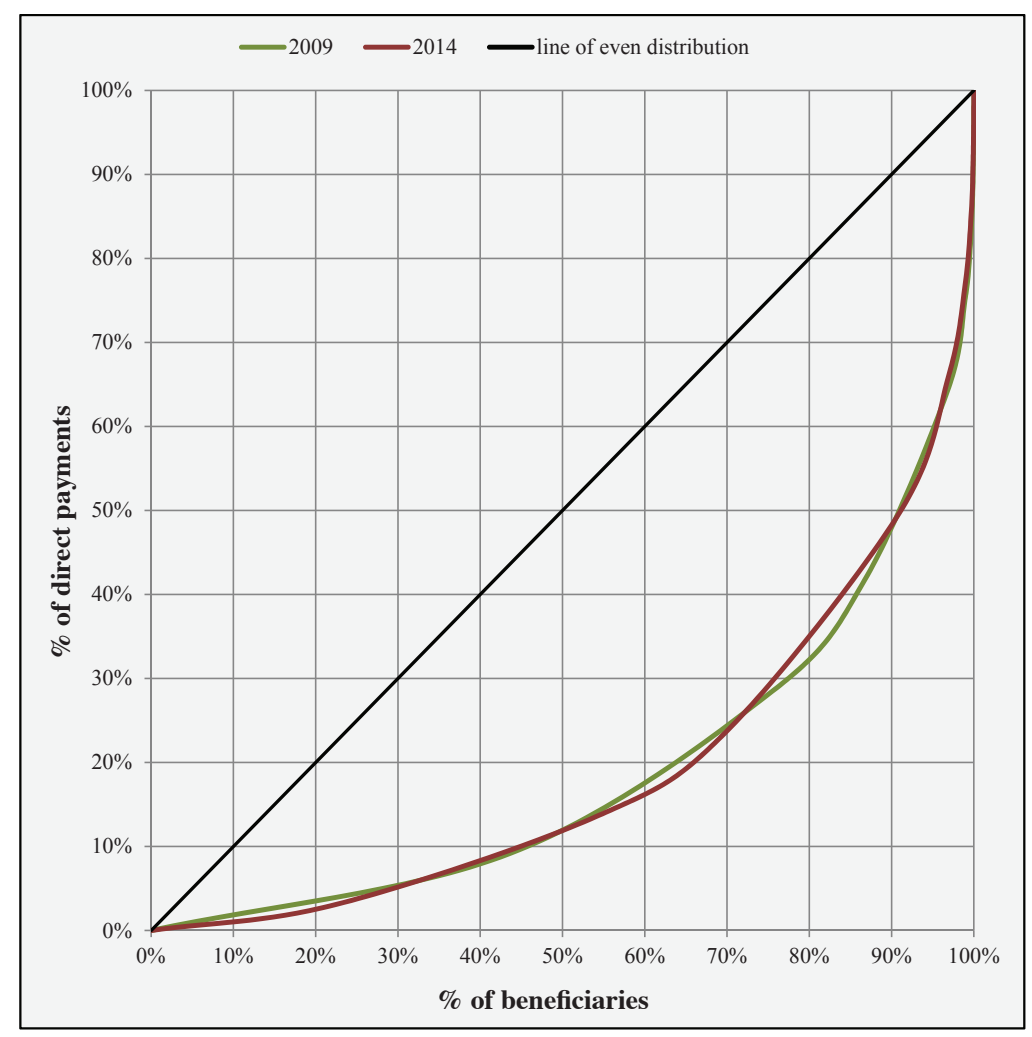

Fig. 1. Curves of direct support concentration in Poland in 2009 and 2014.

Source: own study based on Indicative figures... (financial year 2010) and Indicative figures... (financial year 2015).

It should be noted that the diagonal of the square in Fig. 1 represents an extremely egalitarian principle of support distribution, whereby each beneficiary would receive the same amount of direct payments and, therefore, it is not used as a benchmark. In addition to illustrating the extreme version of the distribution of funds between beneficiaries, the diagonal line, called the line of even distribution, facilitates the graphical interpretation of the Gini coefficient, which is the double of the field formed between the line and the Lorenz curve. As it is impossible to present objectively the desired level of support concentration, it is equally unfeasible to draw up a "model" Lorenz curve, which would serve as a point of reference for comparative studies. Therefore, one way to assess the phenomenon of direct support concentration is to analyse changes in the unequal distribution of support over time. 


\section{International comparison of support concentration}

In addition to the comparative analysis of the degree of direct support concentration in subsequent years, the results of comparisons with other Member States and the EU as a whole may be used as a starting point for assessing the phenomenon within a given Member State. In 2014, the concentration of payments in 6 countries was greater than in the EU as a whole. It was observed in 5 new Member States (Slovakia, the Czech Republic, Bulgaria, Hungary, Estonia) and a single EU-15 Member State, i.e. Portugal. The most uneven distribution of support was observed in Slovakia $\left(G_{S K} \cong 0.89\right)$. Luxembourg, Ireland, Finland, France, Belgium and the Netherlands were at the other end of the spectrum, but only in Luxembourg was the Gini coefficient lower than $0.5\left(G_{L U} \cong 0.61\right)$.

The concentration of direct support in Poland $\left(G_{P L} \cong 0.61\right)$ was significantly lower than in the EU $\left(G_{U E} \cong 0.61\right)$. This phenomenon was similar in Greece $\left(G_{G R} \cong 0.61\right)$ and Slovenia $\left(G_{S I} \cong 0.61\right)$. Compared to Poland, payments were distributed more equally in 8 Member States (Fig. 2).

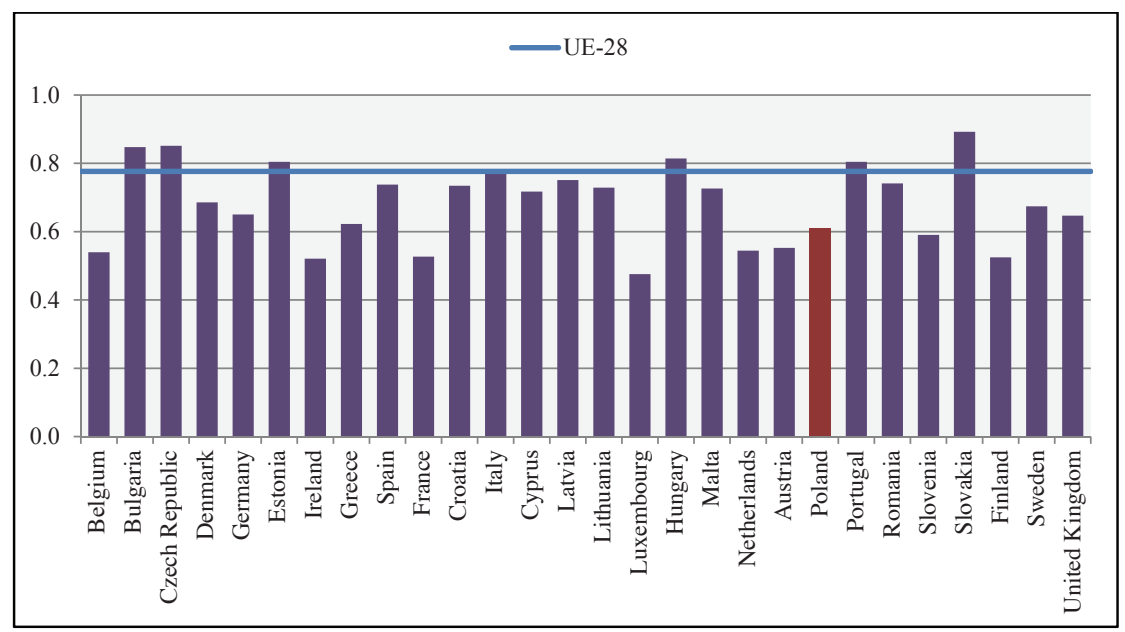

Fig. 2. Coefficient of direct support concentration in Member States in 2014.

Source: own study based on Indicative figures... (financial year 2015).

A more suggestive cross-country comparison affords a graphical presentation of the concentration phenomenon based on the Lorenz curve (Fig. 3). For reasons of clarity, the number of comparable countries was limited to four (Poland, the Czech Republic, France and Germany). 


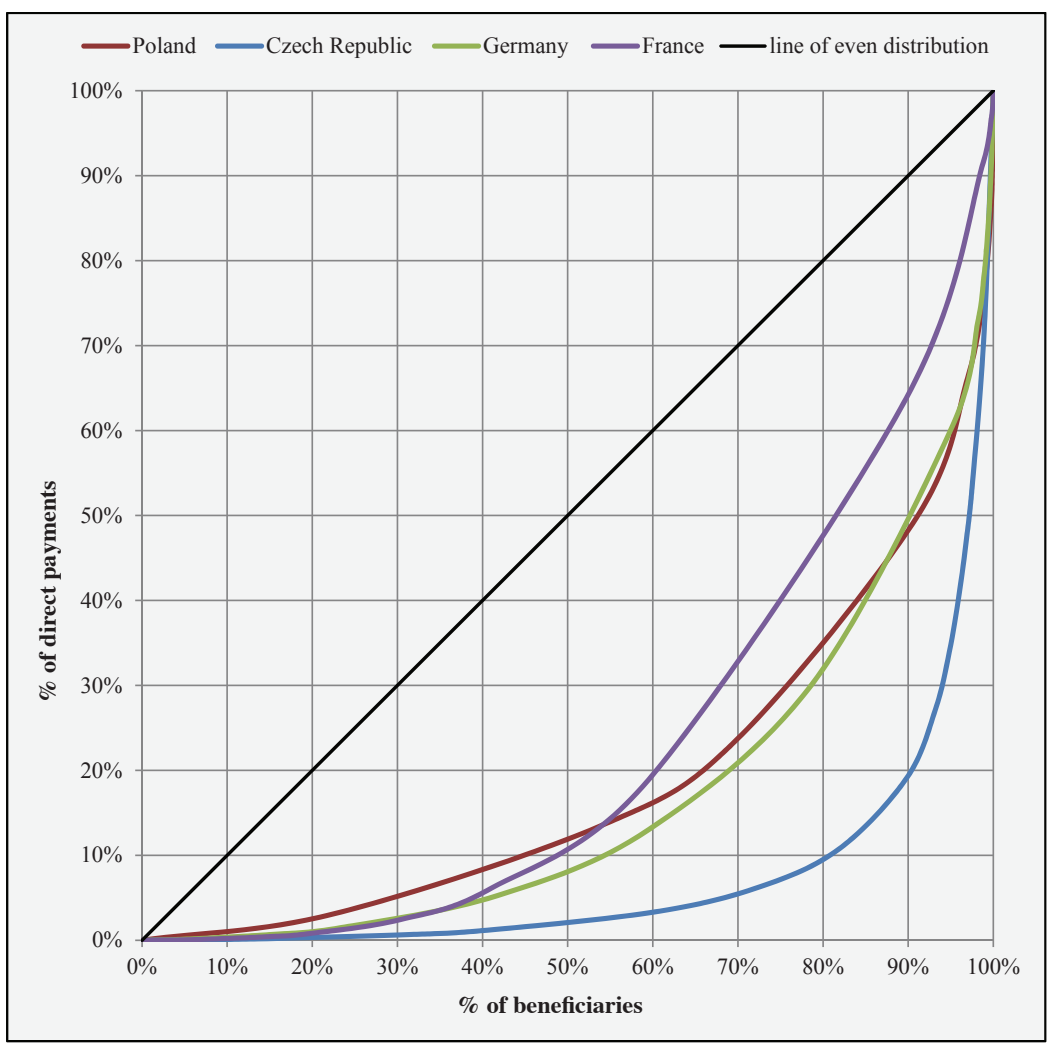

Fig. 3. Direct support concentration curves in selected Member States of the European Union for 2014.

Source: own study based on Indicative figures... (financial year 2015).

The Lorenz curve drawn for Poland is the closest to Germany's curve, which is indicative of a similar degree of concentration of support in these countries. On the left, the curve depicting the concentration of direct payments in Poland is the closest to the line of uniform distribution. This means that, compared to France, Germany and the Czech Republic, the smallest Polish farms represent a relatively large share of the funds allocated to Poland. On the right, the curve of Poland's concentration is crossed by the curve of France, which is the closest to the line depicting equal distribution. On the other hand, the curve drawn for the Czech Republic is the most concave with respect to the centre of the square, which means the strongest concentration of support among the countries subject to comparison. Graphs presented in Figure 3 indicate, for example, that $80 \%$ of the smallest farms receive less than $10 \%$ of the total amount of direct payments in the Czech Republic, while in Poland and Germany, $80 \%$ of the smallest beneficiaries receive over $30 \%$ of total payments; in France their share approximates $50 \%$. 


\section{Instruments reducing disparities in the distribution of resources among beneficiaries}

Following the CAP reform of 2015, two instruments were introduced with a view to partially reduce disparities in the amount of support paid to beneficiaries: payment reduction mechanism and redistributive payment. Payment reduction mechanism replaced the so-called modulation of payment, while redistributive payment was introduced as a new instrument under the direct support scheme.

Payment reduction mechanism applies only to beneficiaries that receive over EUR 150,000 of basic payment ${ }^{4}$. The amount of basic payment exceeding the amount of EUR 150,000 is reduced by at least $5 \%$. This is a mandatory mechanism to be implemented by all Member States that do not use redistributive payments or have allocated for its funding no more than $5 \%$ of the national ceiling.

Member States decide on the level of reduction of the basic payment by selecting a reduction coefficient between 5 and $100 \%$, with the possibility of setting its gradation, i.e. different values for subsequent amount ranges. In addition, they may introduce the principle of subtracting employment costs from the reduction basis, thus mitigating the restrictiveness of this instrument and creating preferences for households benefiting from paid employment. On the other hand, the EU legislation does not allow Member States to extend the scope of this mechanism (limited only to the basic payment) or the option to lower the very high threshold (EUR 150,000). As a consequence, the potential of the payment reduction mechanism as an instrument aimed at reducing the concentration of resources distributed in the form of direct support is rather limited in Poland.

Among the 8 Member States that have allocated more than 5\% of the national ceiling for redistributive payments, Croatia, France, Lithuania, Germany, Romania and Belgium-Wallonia decided against applying the reduction mechanism. Other countries/regions have made the following decisions regarding the implementation of this mechanism (Direct payments 2015-2020...):

1) regarding the reduction coefficient:

- 14 Member States (Cyprus, the Czech Republic, Denmark, Estonia, Finland, Spain, the Netherlands, Luxembourg, Latvia, Malta, Portugal, Slovakia, Slovenia, Sweden) and one region (England) apply a uniform, the lowest possible reduction coefficient of $5 \%$ with regard to the entire surplus of the amount of basic payment exceeding EUR 150,000;

- 3 Member States (Bulgaria, Hungary and Italy) and 2 regions (Wales and Scotland) apply differentiated reduction coefficients for selected ranges (gradation);

\footnotetext{
${ }^{4}$ Meaning basic payments (in countries using the entitlement-based system) or single area payment (in countries using the simplified system).
} 
- 4 Member States (Austria, Greece, Ireland and Poland) and 2 regions (Flanders, Northern Ireland) apply a single, the highest possible reduction coefficient of $100 \%$ for the entire surplus over the basic amount of EUR 150,000, which means that, in fact, the maximum amount of basic payment is EUR 150,000 (unless they apply the principle of labour costs deduction);

2) regarding the deduction of employment costs - 9 Member States (Austria, Bulgaria, Estonia, Greece, Spain, Luxembourg, Latvia, Slovenia, Italy) allow beneficiaries to deduct labour costs from the reduction basis.

This means that although Poland allocated more than 5\% of the national ceiling (more than $8 \%$ ) to redistributive payments, it did not resort to the possibility of cancelling the payment mechanism. Furthermore, given that Member States were allowed to decide on specific options within the mechanism to be applied, Poland chose the option that was most restrictive with respect to large beneficiaries, i.e.:

1) adoption of the highest possible payment reduction coefficient $(100 \%)$ with respect to the total surplus of single area payments exceeding the threshold of EUR 150,000

2) non-application of the rule allowing beneficiaries to deduct employment costs from the reduction basis.

In 2015, the maximum farm size in Poland was set at 1,403.36 ha; the mechanism of payment reduction was applied to farms exceeding this threshold. This was the case of only 116 farms, i.e. fewer than $0.01 \%$ of all direct beneficiaries. The application of the payment reduction mechanism led to savings approximating EUR 16,516,000. This figure represents less than $0.5 \%$ of the national ceiling for 2015. Redistribution scope and effects of the payment reduction mechanism in 2015 are presented in Table 2.

Making greater use of the potential of the payment reduction mechanism as an instrument adjusting support would require increasing the level of single area payment funding. For example, if in $2015,60 \%$ instead of $44.73 \%$ of the national ceiling (i.e. nearly EUR 2.03 billion) were allocated to the single area payment, the rate would stand at EUR 143.38 per ha. The consequence of the higher rate would be the lowering of the maximum farm size beyond which the beneficiary would be subject to the payment reduction mechanism (it would stand at 1,046.16 ha). As a result, the reduction would apply to the majority of farmers and a larger amount would be obtained. On the other hand, a reduction of the level of funding of the single area payment would automatically reduce the number of farms subject to reduction and lower the reduction amount. For example, when financing a single area payment at the level of $20 \%$ of the na-

\footnotetext{
${ }^{5}$ Alternatively, it was possible to adopt several different coefficients (not lower than 5\%) with respect to identified amount ranges. Coefficient gradation was applied, for example, in Bulgaria, where amounts ranging between EUR 150,000 and EUR 300,000 are reduced by 5\%, and amounts exceeding EUR 300,000 by $100 \%$.
} 
tional ceiling (slightly over EUR 675.72 million), the payment would amount to EUR 47.79 per ha and the reduction would apply to farms with a total area exceeding $3,138.50$ ha.

Table 2

Redistribution scope and effects of the payment reduction mechanism in Poland in 2015

\begin{tabular}{|c|c|c|c|c|c|c|c|}
\hline \multicolumn{2}{|c|}{$\begin{array}{c}\text { Level of financing } \\
\text { of the single area } \\
\text { payment }\end{array}$} & \multirow{2}{*}{$\begin{array}{l}\text { Single area } \\
\text { payment } \\
\text { rate } \\
(\text { EUR/ha) }\end{array}$} & \multirow{2}{*}{$\begin{array}{l}\text { Size range } \\
\text { of farms } \\
\text { subject to } \\
\text { reduction }\end{array}$} & \multicolumn{2}{|c|}{$\begin{array}{l}\text { Population of farms } \\
\text { subject to reduction }\end{array}$} & \multicolumn{2}{|c|}{$\begin{array}{l}\text { Resources obtained } \\
\text { through reduction }\end{array}$} \\
\hline $\begin{array}{l}\text { as part of } \\
\text { the national } \\
\text { ceiling }\end{array}$ & $\begin{array}{l}\text { amount } \\
\text { (EUR } \\
\text { million) }\end{array}$ & & & $\begin{array}{l}\text { number } \\
\text { (units) }\end{array}$ & $\begin{array}{c}\text { share } \\
\text { in the total } \\
\text { number of } \\
\text { beneficiaries }\end{array}$ & $\begin{array}{l}\text { amount } \\
\text { (EUR } \\
\text { million) }\end{array}$ & $\begin{array}{l}\text { as part } \\
\text { of the } \\
\text { national } \\
\text { ceiling }\end{array}$ \\
\hline $44.73 \%$ & $1,511.19$ & 106.89 & $\begin{array}{c}\text { from } \\
1,403.37 \text { ha }\end{array}$ & 116 & $0.01 \%$ & 16.52 & $0.49 \%$ \\
\hline
\end{tabular}

Source: own study based on Regulation No. 1307/2013 and ARMA data.

In addition to the payment reduction mechanism, another instrument is in place to reduce disparities between beneficiaries, i.e. the redistributive payment. The use of this instrument is optional for Member States, and its relevance depends to a great extent on decisions taken at the national level, which includes setting the level of funding and the size of agricultural land owned by farms subject to this payment.

Member States can earmark a maximum of $30 \%$ of the national ceiling for financing redistributive payments, which represents the greatest share of all optional instruments ${ }^{6}$; apart from redistributive payments, they include payments for areas with natural constraints, production support and the small farm scheme. In addition to the funding level, the Member State determines the size range of farms that can benefit from support under this instrument. The general framework is defined by the EU regulations, with the lower limit at 0 ha and the upper limit at $30 \mathrm{ha}$, or the average farm size in a given country ${ }^{7}$, whichever of the two is higher. ${ }^{8}$ Within these limits, the Member State indicates the "privileged" area range, which is subject to payments. Redistributive payment is, therefore, not granted to specific agricultural parcels, but to an abstract surface that forms part or the entirety of the farm's actual surface. In order to determine the area covered by this payment in a farm, hectares within that farm need to

\footnotetext{
${ }^{6}$ Subject to the implementation of the small farm scheme in a variant in which participants of the scheme receive exactly the same amount of support they would receive in the standard system, although not exceeding EUR 1,250. In this situation, there is no limit for the financing of the small farms scheme, which stands essentially at $10 \%$ of the national ceiling.

${ }^{7}$ Average farm sizes in respective Member States were given in Annex VIII to Regulation No. 1307/2013..

${ }^{8}$ In Poland, the average size of a farm is less than 30 ha (6 ha), and thus the "privileged" range is comprised between 0 and 30 ha.
} 
be numbered and then those that fall within the "privileged" range are counted. In addition, the EU regulations provide for the principle according to which the redistributive payment rate cannot exceed $65 \%$ of the national average payment per hectare, calculated as the ratio of the national ceiling for 2019 to the area covered by the single area payment in 2015 .

According to Lakner et al. (2013), the use of a redistributive payment by a Member State may have a strong degressive effect, but this cannot be equated with an effective transfer of income or with creating an effective incentive for the delivery of public goods. Following the introduction of this instrument, income protection has become more important as justification for direct payments; this may further hamper their suppression.

In 2015-2016, the system of redistributive payments was applied by $7 \mathrm{Mem}$ ber States (Bulgaria, Croatia, France, Lithuania, Germany, Poland, Romania) and 2 regions (Wales and Wallonia), and since 2017 this instrument shall also be used in Portugal (Redistributive payment, 2016). In 2015-2016, Lithuania earmarked the largest share of the national ceiling for financing redistributive payments (15\%); other countries allocated no more than $10 \%$ of the national ceiling for this purpose. Around EUR 1.5 billion (Direct payments 2015-2020...) were paid out in the form of redistributive payments in this period.

All Member States, with the exception of Croatia and Portugal, have set the upper limit for the hectare range subject to redistributive payment at the maximum acceptable level. Two Member States (Germany and Romania) have adopted the principle of rate gradation, dividing the hectare range subject to support into two distinct ranges. In Germany, the rate is degressive, while Romania has opted for a progressive rate. One Member State (Poland) does not allocate payments to the smallest farms (with an area not exceeding $3 \mathrm{ha}$ ), which can be treated as a special case of rate gradation, with a zero rate for the hectare range $(0 ; 3] .{ }^{9}$ Hectare ranges subject to redistributive payments in each Member State and estimated support rates are specified in Table 3 (data refers to 2015).

In line with assumptions adopted in Poland, redistributive payment support is targeted at a group of medium-sized farms which - despite not benefiting from the same scale of production as the largest farms - have a certain development potential.10 This was the reason for applying redistributive payment to the hectare range $(3 ; 30]$. This means that support is granted to the surplus agricultural area subject to single area payments for farms with a total area of 3-27 ha.

\footnotetext{
${ }^{9}$ It should be stressed that this variant (with zero rate for the "first" hectares) may in certain situations lead to a more uneven distribution of support.

${ }^{10}$ Spychalski (2008) posits that support be directed at producers with development potential in order to improve the effectiveness of state intervention mechanisms in agriculture.
} 
Table 3

Implementation of redistributive payments in countries and regions in 2015

\begin{tabular}{lcc}
\multicolumn{1}{c}{$\begin{array}{c}\text { Member State/ } \\
\text { Region }\end{array}$} & Hectare range subject to support & Estimated rate (EUR/ha) \\
\hline Bulgaria & $(0 ; 30]$ & 77 \\
Croatia & $(0 ; 20]$ & 34 \\
France & $(0 ; 52]$ & 25 \\
Lithuania & $(0 ; 30]$ & 50 \\
Germany & $(0 ; 30]$ & 50 \\
Poland & $(30 ; 46]$ & 30 \\
Romania & $(3 ; 30]$ & 41 \\
Wales & $(0 ; 5]$ & 5 \\
Wallonia & $(5 ; 30]$ & 45 \\
\end{tabular}

Source: Direct payments $2015-2020 \ldots$.

In $2015-2016,8.3 \%$ of the national ceiling was allocated to redistributive payments. As a result, the redistributive payment rate for 2015 amounted to EUR 40.10 per ha (therefore, the maximum amount that could be granted under this payment was EUR 1,082.70 per farm) and in 2016 - EUR 40.01 per ha (which meant a maximum of EUR 1,080.27 per farm). ${ }^{11}$ On the other hand, the consequence of this level of funding of redistributive payments was a decrease in the single area payment rate of nearly EUR 20 per ha. In 2017-2019, the level of funding for redistributive payments is expected to be slightly higher (both as a percentage of the national ceiling and in terms of specific amounts).

The actual level of funding for redistributive payments in Poland, the rate of this payment in subsequent years and the scale of the reduction of the single area payment rate as a result of the allocation of a certain amount from the national ceiling for the implementation of redistributive payments are presented in the upper part of Table 4. Data on the impact of redistributive payments on the single area payment rate after 2017 are estimated based on the assumption

\footnotetext{
${ }^{11}$ In the case of Poland, the average national payment per hectare is EUR 244.05/ha and, therefore, the redistributive payment rate cannot exceed EUR 158.64/ha (in accordance with the above principle, the redistributive payment rate must not exceed $65 \%$ of national average payment per hectare). Table 4 shows that this limitation would not actually reduce the redistributive payment rate granted in accordance with currently applicable rules, even if the financing of this payment has been increased to a maximum level.
} 
that Poland will not change its plans regarding the level of funding dedicated to redistributive payments. However, maximum amounts available for redistribution in Poland in subsequent years and the corresponding rates of these payments, as well as the impact of the adopted maximum level of funding for redistributive payments for the single area payment rate, are shown in the lower part of Table 4.

Table 4

Funding level and redistributive payment rate in Poland in 2015-2020 and its effects on the application of the single area payment rate

\begin{tabular}{|c|c|c|c|c|c|c|c|}
\hline & 2015 & 2016 & 2017 & 2018 & 2019 & 2020 & Total \\
\hline \multirow{2}{*}{ 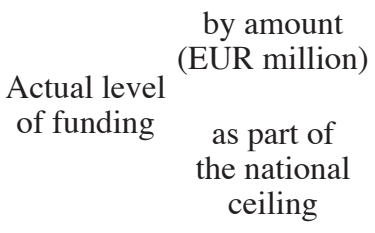 } & 280,42 & 281,81 & 289,80 & 293,93 & 298,04 & 254,11 & 1,698.11 \\
\hline & $8.30 \%$ & $8.30 \%$ & $8.49 \%$ & $8.57 \%$ & $8.64 \%$ & $8.30 \%$ & $\mathbf{x}$ \\
\hline $\begin{array}{l}\text { Actual rate } \\
\text { (EUR/ha) }\end{array}$ & 40.10 & 40.01 & $41.29^{a}$ & $41.88^{\mathrm{a}}$ & $42.46^{\mathrm{a}}$ & $36.20^{\mathrm{a}}$ & $\mathbf{x}$ \\
\hline $\begin{array}{c}\text { Impact on the single } \\
\text { area payment rate } \\
\text { (EUR/ha) }\end{array}$ & -19.83 & -19.86 & $-20.46^{b}$ & $-20.75^{b}$ & $-21.04 b$ & $-17.94^{b}$ & $\mathbf{x}$ \\
\hline $\begin{array}{l}\text { Maximum level of funding } \\
\text { (EUR million) }\end{array}$ & $1,013.58$ & $1,018.59$ & $1,023.56$ & $1,029.37$ & $1,035.15$ & 918.46 & $6,038,71$ \\
\hline $\begin{array}{c}\text { Rate at the maximum } \\
\text { level of financing } \\
\text { (EUR/ha) }\end{array}$ & 144.94 & 144.60 & $145.84^{\mathrm{a}}$ & $146.66^{\mathrm{a}}$ & $147.49^{\mathrm{a}}$ & $130.86^{a}$ & $\mathbf{x}$ \\
\hline $\begin{array}{l}\text { Impact on the single } \\
\text { area payment rate } \\
\text { (EUR/ha) }\end{array}$ & -71.69 & -71.80 & $-72.27^{b}$ & $-72.68^{b}$ & $-73.09^{b}$ & $-64.85^{b}$ & $\mathbf{x}$ \\
\hline
\end{tabular}

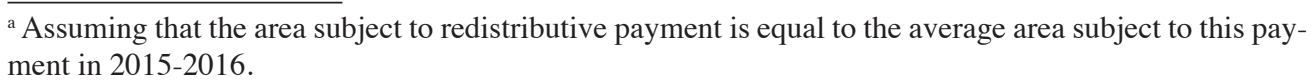

${ }^{\mathrm{b}}$ Assuming that the area subject to single area payment is equal to the average area subject to this payment in 2015-2016.

Source: own study based on Regulation No. 1307/2013 and ARMA data.

Table 5 presents calculations on the basis of which limit values were set for the redistribution effect of the farm size. This implies that in 2015, farms with an area of less than 5.9 ha and farms larger than 54.6 ha lost out on redistributive payments in their current form, i.e. they would have received greater support if this payment had not been applied and the funds allocated to its financing 
would have been paid under the single area payment. Farms with an area between 5.9 ha and 54.6 ha benefit from redistributive payments. From the point of view of farms with threshold areas, the application of this instrument is neutral in terms of the amount of payment received. Thus, the size range of farms benefiting from the redistributive payment ( 5.9 ha; $54.6 \mathrm{ha}$ ) is wider than the "privileged" range of hectares ( 3 ha; 30 ha] and shifted to the right.

Table 5

Determining the size of farms benefiting from redistributive payments in Poland in 2015

VARIANT
- level of funding of
single area
and redistributive
payment

The amount of support

$$
\begin{array}{cc}
\text { under the single } & \text { Limit values for the farm size (ha) } \\
\text { area payment } & \text { redistribution effect }
\end{array}
$$

\section{Limit values for the farm size (ha)} and the

redistributive payment (EUR)

$$
\begin{aligned}
& \text { ZERO VARIANT } \\
& \text { single area } \\
& \text { payment }-53.03 \% \\
& \text { of the national ceiling } \quad x \times P R_{S A P 0} \\
& (44.73 \%+8.3 \%) \\
& \text { redistributive payment - } \\
& 0 \% \text { of the national ceiling } \\
& \begin{array}{c}
x_{1} \square 126,72=x_{1} \square 106,88+\left(x_{1}-3\right) \square 40,10 \\
x_{1} \cong 5,9
\end{array} \\
& x_{2} \square 126,72=x_{2} \square 106,88+27 \square 40,10 \\
& x_{2} \cong 54,6 \\
& \begin{array}{c}
x \times P R_{S A P 1}+(x-3) \times P R_{R} \\
\text { dla } x \leq 30 \\
x \times P R_{S A P 1}+27 \times P R_{R} \\
\text { dla } x>30
\end{array}
\end{aligned}
$$

Where:

$x$ - farm area (ha);

$P R_{S A P 0}=126.72 E U R / h a-$ hypothetical rate of single area payment for 2015, which would apply if the zero variant was adopted;

$P R_{S A P 1}=106.88 E U R / h a-$ actual rate of single area payment for 2015;

$P R_{R}=40.10 E U R / h a \quad-$ the actual redistributive payment rate for 2015

Source: own study.

In 2015 , redistributive payments were received by nearly 896,000 of Polish farmers, i.e. approximately $66 \%$ of all beneficiaries of direct support. The total area covered by the redistributive payment was less than 7 million ha, which accounted for nearly half of the area subject to single area payments. By contrast, 
in 2016, the number of redistributive payment beneficiaries exceeded 900,000 (nearly $67 \%$ of all applicants) and the area subject to payment was over 7 million ha (almost half of the area covered by the single area payment).

\section{Summary}

From the analysis of changes in the concentration of direct payments in Poland in 2009-2014, it can be concluded that in the subsequent years of the period covered by the study, this value remained almost unchanged and, therefore, it should be regarded as very stable. On the other hand, geographical comparisons show that in terms of the distribution of support among beneficiaries in 2014, Poland ranked $9^{\text {th }}$ among the EU Member States. Support intensity measured with the Gini coefficient is much lower in Poland than in the EU as a whole.

The CAP reform of 2015 introduced two instruments to reduce disproportions in the amount of support paid to beneficiaries, namely the payment reduction mechanism (which replaced the so-called payment modulation) and the redistributive payment (a new instrument). The most restrictive (from the point of view of the largest farms) variant of the mechanism of payment reduction was implemented only by Ireland and Poland, although in the year preceding its implementation, support concentration in these countries was relatively low. At the same time, Member States have made little use of the relatively great potential of redistributive payments to bridge the uneven distribution of support. In the country that has allocated the largest part of the national ceiling to this payment, i.e. in Lithuania, the level of funding for this payment stands at $15 \%$, which represents half of the acceptable limit. ${ }^{12}$

An analysis of the manner in which countries implement measures to reduce disproportions in the amount of support per beneficiary shows that the degree of use of the redistribution potential of these instruments by a given Member State does not depend on the evenness of distribution of support among farmers. This may testify to differences in how decision-makers from different countries define fairness of support distribution.

In the author's view, the payment reduction mechanism should not be limited to the basic payment, but ought to apply to the surplus of all direct payments (i.e. the basis for the reduction should be the surplus of the total amount of all direct payments above a specific threshold). In addition, it should be possible to adjust (down) the amount threshold at the Member State level, in order to take into account the local situation, in particular the share of potentially eligible farms in the total number of beneficiaries. As a result, the redistribution potential of this mechanism would be greater. The application of the payment reduction mechanism is complicated by the shifting of funds to the second pil-

\footnotetext{
${ }^{12}$ At the same time, Lithuania has decided against applying the payment reduction mechanism.
} 
lar of the CAP. ${ }^{13}$ Redistributive payments do not bring about such administrative difficulties; however, in their present form, they fail to limit the amount of support received by the largest beneficiaries as efficiently as the mechanism of reduction does. It seems that Member States rarely avail themselves of the possibility to gradually increase the importance of redistributive payments through raising funding levels. In this way, abrupt changes in the amount of beneficiaries' income generated through direct payments could be avoided, as the target level of funding for redistributive payments would only be reached upon the end of the transitional period. ${ }^{14}$

\footnotetext{
${ }^{13}$ In view of the multiannual perspective of the EU budgetary plans, the adjustment of national ceilings due to the application of the payment reduction mechanism is based on the effects of the application of the mechanism by individual Member States over the entire period between 2015 and 2019, and it is not subject to adjustments. As a consequence, if the actual amount obtained for the reduction of payments in a given year is less than the amount notified to the Commission, the Member State is obliged to implement a relevant linear reduction of all direct payments, to ensure that the total amount of payments does not exceed the adjusted national ceiling. The result of the revaluation of the amount obtained through the reduction of payments is the transfer of funds to the second pillar "financed" by the beneficiaries of direct payments in proportion to the amounts received. If, however, the actual amount resulting from the payment reduction mechanism is higher than the estimated amount in a given year, the Member State de facto "loses" the EU funds, i.e. the sum representing the difference between these amounts. This is due to the fact that the limit for direct payments will not be fully utilized, and resources from the rural development programme - due to the rigidity of the established support limit - resulting from the procedures in place - will not be proportionately increased. These technical conditions complicate the scheme. Member States may find themselves unable to use all of the allocated funding.

${ }^{14}$ This is best exemplified by France, which has allocated 5\% of its national ceiling in 2015 to redistributive payments; in 2016-2017, it has allocated $10 \%$ of its ceiling and plans to increase this share to $20 \%$ in 2018-2020.
} 


\section{References}

A Common Agricultural Policy for European Public Goods (2009). Declaration by a Group of Leading Agricultural Economists. Retrieved from: http://reformthecap.eu/pl/posts/ declaration-on-cap-reform.

Czyżewski, A., Stępień, S. (2011). Wspólna polityka rolna UE po 2013 r. a interesy polskiego rolnictwa. Ekonomista, no. 1, pp.9-36.

Direct payments 2015-2020. Decisions taken by Member States: State of play as at June 2016. European Commission.

Hamulczuk, M., Rembisz, W. (2009). Kwestie wyrównania dopłat bezpośrednich producentom rolnym w Unii Europejskiej. Problemy Rolnictwa Światowego, vol. 9(24), pp. 35-45.

Indicative figures on the distribution of aid, by size-class of aid, received in the context of direct aid paid to the producers according to council regulation (EC) no 73/2009 (financial year 2015). European Commission.

Indicative figures on the distribution of aid, by size-class of aid, received in the context of direct aid paid to the producers according to council regulation (EC) no 73/2009 (financial year 2010). European Commission.

Krzyżanowski, J. (2015). Wyrównywanie poziomu płatności bezpośrednich w Polsce do poziomu innych krajów Unii Europejskiej. Zagadnienia Ekonomiki Rolnej, no. 4(345), pp. 3-15.

Lakner, S., Holst, C., Brümmer, B., von Cramon-Taubadel, S., Theuvsen, L., Mußhoff, O., Tscharntke, T. (2013). Zahlungen für Landwirte an gesellschaftliche Leistungen koppeln! - Ein Kommentar zum aktuellen Stand der EU-Agrarreform. Retrieved from: http:// ageconsearch.umn.edu/record/187588/files/Diskussionsbeitrag\%20GAP-Reform\%20 2013\%20vor\%20Trilog.pdf.

Redistributive payment (2016). European Commission.

Regulation (EU) No. 1307/2013 of the European Parliament and of the Council of 17 December 2013 establishing rules for direct payments to farmers under support schemes within the framework of the common agricultural policy and repealing Council Regulation (EC) No. 637/2008 and Council Regulation (EC) No. 73/2009 OJ L 347, 20.12.2013, p. 608, as amended).

Sinabell, F., Schmid, E., Hofreither, M.F. (2009). The distribution of Direct Payments of the Common Agricultural Policy. Jahrbuch der Österreichischen Gesellschaft für Agrarökonomie, vol. 18(1), pp. 111-119.

Spychalski, G. (2008). Działania interwencyjne w rolnictwie i na obszarach wiejskich w Polsce. Ekonomika i Organizacja Gospodarki Żywnościowej, no. 71, pp. 43-52.

Wasilewska, E. (2011). Statystyka opisowa od podstaw. Podręcznik z zadaniami. Warszawa: Wydawnictwo SGGW.

Wilkin, J. (2009). Ekonomia polityczna reform Wspólnej Polityki Rolnej. Gospodarka Narodowa, no. 1-2, pp. 1-25.

Zawojska,A.(2006). Społeczno-ekonomiczne aspekty dopłat bezpośrednich w UE. Roczniki Naukowe Stowarzyszenia Ekonomistów Rolnictwa i Agrobiznesu, vol. 8, issue 4, pp. 400-404. 
ADRIAN SADŁOWSKI

Szkoła Główna Handlowa

Warszawa

\title{
PODZIAŁ ŚRODKÓW W RAMACH SYSTEMU WSPARCIA BEZPOŚREDNIEGO POMIĘDZY BENEFICJENTÓW - ANALIZA NIERÓWNOMIERNOŚCI I INSTRUMENTY REDYSTRYBUCYJNE WPROWADZONE W 2015 ROKU
}

\begin{abstract}
Abstrakt
W artykule dokonano analizy nierównomierności rozdziału pomiędzy beneficjentów pomocy unijnej realizowanej $w$ ramach systemu wsparcia bezpośredniego oraz oceny stopnia wykorzystania przez państwa członkowskie Unii Europejskiej potencjału redystrybucyjnego instrumentów wprowadzonych reforma wspólnej polityki rolnej z 2015 roku. Sa to kwestie szczególnie istotne w kontekście dązenia do zapewnienia sprawiedliwego podziału środków przeznaczonych na wsparcie rolnictwa, nie osłabiając przy tym bodźców stużacych podnoszeniu efektywności.

Źródtem danych empirycznych były opracowane przez. Komisje Europejska zestawienia łącznych kwot płatności bezpośrednich wypłaconych na rzecz beneficjentów w podziale na państwa członkowskie UE $i$ przedziały kwotowe wsparcia. W badaniach zastosowano metody statystyki opisowej, analize porównawcza i symulacje.

Stwierdzono, że stopień wykorzystania potencjału redystrybucyjnego instrumentów zmniejszających dysproporcje $w$ wysokości wsparcia na beneficjenta przez dane państwo nie zależy od jego miejsca pod względem nierównomierności podziału środków między rolników. Może to świadczyć o różnym wyobrażeniu decydentów w poszczególnych państwach o sprawiedliwym rozdziale wsparcia. Ponadto sformułowano pewne rekomendacje $w$ odniesieniu do instrumentów redystrybucyjnych wprowadzonych reforma WPR z 2015 roku. Wopinii autora mechanizm redukcji płatności nie powinien być ograniczony wyłacznie do płatności podstawowej, poza tym powinna zostać zapewniona możliwość dostosowania progu kwotowego na poziomie państwa członkowskiego. Zwiększyłoby to potencjał redystrybucyjnytego mechanizmu. Jednocześnie, zdaniem autora, państwa członkowskie w zbyt małym stopniu korzystaja z możliwości zwiększania znaczenia płatności redystrybucyjnej poprzez podnoszenie poziomu finansowania tego instrumentu. Takie rozwiazanie pozwala stopniowo zmniejszać stopień koncentracji wsparcia, unikajac przy tym gwattownych zmian w sytuacji dochodowej beneficjentów płatności bezpośrednich.
\end{abstract}

Słowa kluczowe: płatności bezpośrednie, koncentracja wsparcia, współczynnik Giniego, krzywa Lorenza, płatność redystrybucyjna.

Accepted for print: 12.12.2017.

Unless stated otherwise all the materials on the website are available under the Creative Commons Attribution 3.0 Poland license. Some rights reserved to the Institute of Agricultural and Food Economics - National Research Institute.

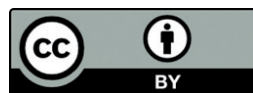

